\title{
Making Native-Language Policy in Ontario in the 1980s
}

\author{
John S. Long
}

The 1979-80 Northern Native-Languages Project was influential in developing provincial policy for teaching Native languages as subjects of instruction, and for certifying Native-language teachers in Ontario. It also led to the development of culturally relevant English-as-a-second-language materials for use in schools serving Native students in northern Ontario. The project was unable, however, to advance the notion of Native languages as languages of instruction. This article will summarize its key recommendations, examine the reactions of the stakeholders, describe the policy-making processes and the policy decisions, and examine the impact of those decisions, particularly on the role of Native languages in Ontario schools. Although the Ontario Ministry of Education, often viewed as an obstacle in the advancement of Native education, was prepared to fully endorse the use of Native languages as instructional languages, opposition from officials in the Ontario Regional Office of the Department of Indian Affairs and Northern Development caused the province to abandon this position. The suppression of Native languages in church-operated federal residential schools is often cited as a factor in the declining use of those languages and it is often assumed that the federal government's 1973 commitment to Indian Control of Indian Education (ICIE) heralded significant changes in Indian education. This study shows that, despite ICIE, policy decisions in Ontario served to continue the suppression of Native languages, assigning them a token role in virtually all Ontario schools operated by the federal government and by provincial school boards. While policy-makers recognized that many northern Native students experienced difficulties with school achievement, they attributed these learning problems to an English deficit; their solution was to immerse students in English.

Le Projet des langues autochtones du Nord de 1979-1980 influença le développement d'une politique provinciale pour l'enseignement des langues autochtones en tant que matières d'enseignement et pour la certification des enseignants en langues autochtones en Ontario. Il amena aussi le développement d'un matériel pédagogique d'enseignement de l'anglais langue seconde culturellement approprié, destiné aux écoles fréquentées par les étudiants autochtones du nord de l'Ontario. Le projet fut toutefois incapable de faire progresser l'idée de langues autochtones comme langues d'enseignement. Cet article résume les principales recommandations du projet, examine les réactions des intéressés, décrit le processus d'élaboration de la politique ainsi que les décisions politiques qui en découlèrent, et examine l'impact de ces décisions, particulièrement en ce qui concerne le rôle des langues autochtones en Ontario. Bien que le ministre ontarien de l'éducation, souvent perçu comme un obstacle à l'avancement de l'éducation autochtone, fût prêt à appuyer entièrement l'usage des langues autochtones comme langues d'enseignement, l'opposition de 
fonctionnaires du Bureau régional ontarien du ministère des Affaires indiennes et du développement du Nord fit en sorte que la province abandonna le projet. La suppression des langues autochtones dans les pensionnats fédéraux gérés par l'Eglise est souvent mentionnée comme étant l'un des facteurs de l'utilisation décroissante de ces langues. On suppose aussi souvent que l'engagement du gouvernement fédéral de 1973 envers l'énoncé de principe La maîtrise indienne de l'éducation indienne (MIÉI) annonça des changements importants dans l'éducation indienne. Cette étude montre que, malgré le MIÉI, les décisions politiques ontariennes contribuèrent à la suppression des langues autochtones, leur attribuant un rôle symbolique dans pratiquement toutes les écoles de l’Ontario dirigées par le gouvernement fédéral et par les conseils scolaires provinciaux. Alors que les décideurs reconnaissaient que bon nombre d'étudiants autochtones du Nord éprouvaient des difficultés sur le plan de la réussite scolaire, ils attribuèrent ces problèmes d'apprentissage à des carences en anglais; leur solution fut l'immersion anglaise des étudiants.

"It is of prime importance," states the Programme of Studies that set out Ontario's education policy for its elementary schools from the 1930s until the mid-1960s, "that children learn to speak and write their mother tongue clearly, accurately, and gracefully, and to use good books as a source of information and pleasure."1 The 1937 curriculum signalled a shift in the province to the "progressive principles" then associated with the American John Dewey. ${ }^{2}$ Classrooms would now be stimulating environments that developed children's self-confidence and promoted co-operation, tolerance, and knowledge of the local community. Children would learn through play, experimentation, and self-expression. ${ }^{3}$

They would learn in English, however, no matter what their mother tongue, for the then-progressive curriculum was also ethnocentric; it assumed that "English rightly occupies first place among the intellectual exercises of the elementary school." ${ }^{4}$ This linguistic hegemony in Ontario began to change during the 1960s, in the face of Quebec nationalism and Franco-Ontarian demands. ${ }^{5}$ In

$1 \quad$ Programme of Studies for Grades I to VI of the Public and Separate Schools, 1941 (Toronto: Ontario Department of Education, 1941), 35 (emphasis added).

2 William G. Fleming, Education: Ontario's Preoccupation (Toronto: University of Toronto Press, 1972), 184.

3 William G. Fleming, Ontario's Educative Society. Volume III: Schools, Pupils, and Teachers (Toronto: University of Toronto Press, 1971), 3-4.

$4 \quad$ Programme of Studies for 1941, 35; Programme of Studies for Grades 1 to 6 of the Public and Separate Schools, 1960 (Toronto: Ontario Department of Education,1960), 29.

5 Fleming, Schools, Pupils, and Teachers, 345-48; Robert D. Gidney, From Hope to Harris: The Reshaping of Ontario's Schools (Toronto: University of Toronto Press, 1999), 142-47; Don Cartwright, "French-language services in Ontario: a policy of 'overly prudent gradualism'?” in Language and Politics in the United States and Canada: Myths and Realities, ed. Thomas Ricento and Barbara Burnaby (Mahwah: Lawrence Erlbaum 
1968 the Conservative government of Premier John Robarts legally recognized the rights of francophones to vernacular education. ${ }^{\circ}$ The 1982 Canadian Charter of Rights and Freedoms led to further acknowledgement of francophone education rights. ${ }^{7}$

But were government policy-makers in Ontario, in the 1980s, ready to endorse the use of Native languages as languages of instruction $?^{8}$ This study aims to document events and processes of the past, with a view to understanding how policy decisions about vernacular-language education for Native students were made in Ontario in the early 1980s. It complements studies of Indian Affairs policy development at the national level, the role of Indian Affairs officials in policy implementation, and of Native educational policy development at the national and community levels. ${ }^{9}$ It contributes to our understanding of the development of Native-language policy in Canada, the origins of provincial Native-language curriculum guidelines, and the origins of the Circle Program. ${ }^{10}$ Ultimately, it may

Associates, 1998), 273-99.

6 Fleming, Schools, Pupils, and Teachers, 348-49.

7 Gidney, Hope to Harris, 147-49.

$9 \quad$ Key studies at the national level include Katherine Graham, Public Policy and Aboriginal Peoples, 1965-1992. Volume 1: Soliloquy and Dialogue, Overview of Major Trends in Public Policy Relating to Aboriginal Peoples (Ottawa: Royal Commission on Aboriginal Peoples, 1996) and G. Bruce Doern, "The Politics of Slow Progress: Federal Aboriginal Policy Processes. A Study Prepared for the Royal Commission on Aboriginal Peoples," in For seven generations: an information legacy of the Royal Commission on Aboriginal Peoples (Ottawa: Libraxis, 1997). Two important studies of Indian Affairs officials are E. Brian Titley, A Narrow Vision: Duncan Campbell Scott and the Administration of Indian Affairs in Canada (Vancouver: University of British Columbia Press, 1986) and Robin J. Brownlie, A Fatherly Eye: Indian Agents, Government Power, and Aboriginal Resistance in Ontario, 1918-1939 (Toronto: University of Toronto Press, 2003). Jerald E. Paquette's Aboriginal Self-Government and Education in Canada (Kingston: Queen's University, 1986), his "Purpose, Parity and Conflict: Policy and Conflict in Two Northwestern Ontario Native School Jurisdictions” (Ph.D. diss., University of Toronto, 1986), and Barbara Burnaby and Marguerite MacKenzie's "Cree Decision Making Concerning Language: A Case Study,” Journal of Multilingual and Multicultural Development 22, 3 (2001): 191-209 are valuable studies of Nativeeducation policy at the community level.

10 For Native-language policy in Canada see Barbara Burnaby's "Aboriginal Language Maintenance, Development, and Enhancement: A Review of the Literature,” in Stabilizing Indigenous Languages, ed. Gina Cantoni (Flagstaff: Northern Arizona University, 1996) <http://www.ncela.gwu.edu/pubs/stabilize/i-needs/aboriginal.htm> and Mark Fettes and Ruth Norton's "Voices of Winter: Aboriginal Languages and Public Policy in Canada," in Aboriginal Education: Fulfilling the Promise, ed. Marlene Brant Castellano, Lynne Davis, and Louise Lahache (Vancouver: University of British Columbia Press, 2000), 29-75. On the Circle Program, see Barbara Burnaby, "Circle: An ESL Reading Program for Cree and Ojibwe Speaking Children,” Networks 1, 1 (1984): 7-10; and her "Initial Literacy in Two ESL Programs. ELT Documents," Language Issues and Education Policies 119 (1984): 99-112. 
assist us in understanding the role of government policy in the declining use of Native languages in Ontario and other regions of Canada. ${ }^{11}$

The focus of this historical study is on federal and provincial policy-making, although it is recognized that three nascent Aboriginal organizations operated on the margins of government policy-making in Ontario at this time. ${ }^{12}$ The present study is based on documents obtained through Access to Information requests of the federal Department of Indian Affairs and Northern Development (hereafter DIAND), and on interviews with officials and former officials of DIAND, the Ontario Ministry of Education (hereafter Ministry), and the Native organizations.

\section{The Northern Native-Languages Project, 1979-80}

The Northern Native-Languages Project (NNLP) was co-chaired by two Indian educators: Mariana Couchie, representing DIAND, and Keith Lickers, representing the Ministry. Besides the two governments, it also involved, marginally, three Native organizations. ${ }^{13}$ A research team of emerging academic experts (educators Barbara Burnaby and Kelleen Toohey, and linguist John D. Nichols) was contracted and the research funds were administered by the Northern Nishnawbe Education Council (hereafter Education Council). Under the leadership of Barbara Burnaby, in 1979 the team conducted a literature survey that comprised its Preliminary Report and then visited twenty northern Ontario communities, mainly "remote" fly-in Native communities. ${ }^{14}$

11 Mark Fettes, “Life On The Edge: Canada’s Aboriginal Languages Under Official Bilingualism," in Language and Politics in the United States and Canada, ed. Thomas Ricento and Barbara Burnaby, 117-49; Suzanne Romaine, “The Impact of Language Policy on Endangered Languages," International Journal on Multicultural Societies 4, 2 (2002) <http://www.unesco.org/most/v14n2romaine.pdf>; Waabibizhikiikwe (Patricia M. Ningewance), Dreaming in a strange language: a report on the Native language development project, Sioux Lookout district (Sioux Lookout: Northern Nishnawbe Education Council, 1993); Mary Jane Norris, "Canada's Aboriginal Languages," Canadian Social Trends (Winter 1998): 8-16.

12 The views of Cree and Ojibwe community leaders and teachers, and of the three organizations, are explored in John S. Long, "An Idea Ahead of its Time: Vernacular Language Education for Northern Ontario," in Papers of the $36^{\text {th }}$ Algonquian Conference, ed. H.C. Wolfart (Winnipeg: University of Manitoba, in press).

13 On the origins of the NNLP and on the role of Native organizations, see ibid.

14 Barbara Burnaby, John D. Nichols, and Kelleen Toohey, "Preliminary Report of the Core Team to the Northern Native Languages Project, August 1979.” The team visited fifteen schools operated by DIAND: nine in northwestern Ontario (Angling Lake [Wapekeka], Bearskin Lake, Big Trout Lake, Cat Lake, Kasabonika Lake, Kingfisher Lake, Pikangikum, Sandy Lake and Weagamow Lake [North Caribou Lake]); five in 
The Final Report of the NNLP explained that when children came to school speaking only their Native language, educators had five options for language education: English immersion (Native-language submersion), English with translation, English with translation plus one or more courses in the Native language, vernacular transition, and maintenance bilingual. The most prevalent model was English immersion with translation, which the authors deemed to be moderately effective when teachers used English-as-a-secondlanguage (ESL) techniques. Vernacular transition programs, whereby the Native language is the initial language of formal instruction, were already in place in neighbouring Manitoba, Quebec, and the Northwest Territories, as well as Saskatchewan, but none existed in Ontario. ${ }^{15}$ The authors reported that early school achievement was higher, the second language was learned more easily, and students developed better reading skills with the vernacular transition model. Maintenance bilingual programs, whereby Native students' initial language is the Native language and the Native language continues to play a significant instructional role alongside English (and/or French), did not exist in Canada at this time. ${ }^{16}$

The authors of the Final Report took pains to "not make recommendations on the selection of one or the other program for any particular community.” They emphasized that the Native communities should be allowed to identify their own objectives for education and for language programs. They sought to empower Indian communities, recommending "a public information campaign of at least several months to tell people about the range of program possibilities...the relative costs in terms of manpower, funding and time, and the effects that can be expected from them." ${ }^{\prime 7}$ When it came to vernacularlanguage education, however, empowering the communities would have threatened the careers of DIAND's Superintendent of Education

north-central Ontario (Constance Lake, Fort Hope [Eabametoong], Lansdowne House [Neskantaga], Long Lac [Ginoogaming] and Webequie); and one in northeastern Ontario (Fort Albany). They also saw five schools under provincial jurisdiction (Slate Falls in the northwest; Hearst and Summer Beaver [Nibikamik] in north-central; Moosonee and Moose Factory in the northeast). Barbara Burnaby, John D. Nichols, and Kelleen Toohey, “Northern Native Languages Project, Final Report, March 1980," 5.

15 Verna J. Kirkness, Manitoba Native Bilingual Program; The Manitoba Native Bilingual Program Pilot Project (Winnipeg: Manitoba Department of Education, 1975); Burnaby and McKenzie, "Cree Decision Making Concerning Language”; Bilingual Education: An Overview and Recommendations (Yellowknife: Northwest Territories Department of Education, 1981), 22-26; Learning Tradition \& Change in the Northwest Territories (Yellowknife: Special Committee on Education, 1982), 87-102; Florence Poorman, "Red Earth Pupils to Get Cree, English Instruction," Saskatchewan Indian 72, 2 (Feb. 1977): 7 <www.sicc.sk.ca/saskindian/a77feb07.htm> accessed 9 Feb. 2005.

16 Burnaby, Nichols, and Toohey, "Final Report," 9-13.

17 Ibid., 15. 
in Ontario Region, "Art Griffith,"18 and his peers. Former DIAND official "Larry Sands” observed: "They all had mortgages and families and couldn't afford to be marginalized (polite way of saying fired, or forced out). Program became secondary to survival." ${ }^{19}$ Sands' judgement may be too harsh; the federal budget left DIAND officials with few program options in the 1980s. ${ }^{20}$

The Final Report made recommendations in four broad areas: ESL training, support, and materials; Native languages as subjects of instruction; vernacular-language education; and the training and certification of Native-language teachers. The authors cautioned that "a great deal of ground work [would] have to be laid before Native medium programs such as Vernacular Transition or Maintenance Bilingual should be attempted."21 This warning was certainly an understatement. There were three Native languages (Cree, Ojibway, and Oji-Cree) in northern Ontario. And if DIAND had moved towards even a vernacular transition approach in the north, it would have quickly been pressured by at least some southern communities to develop additional materials in southern Ojibway, Mohawk, Cayuga, and perhaps other languages. Widely spoken languages like Cree, Ojibway, and Oji-Cree had numerous dialects, competing writing systems, and no agreement on common orthographies. The complexities and diseconomies of scale involved in developing such Native-language materials would have required DIAND funding and personnel levels that were simply impossible in the economic climate of the 1980s.

The NNLP researchers recommended that a three-member Steering Committee (with one representative each from DIAND, the Ministry, and the Native organizations) be established to disseminate the report and to make and maintain contact with the agencies responsible for its implementation. ${ }^{22}$ Instead, the three parties went their separate ways for the next couple of years.

18 A pseudonym.

19 Sands (pseudonym), e-mail to author, 6 Oct. 2003.

20 During the late 1970s in northern Quebec, where the James Bay and Northern Quebec Agreement provided for the creation of a Cree School Board with extensive modifications to the provincial curriculum (including vernacular-language education) and elimination of federal jobs, negotiations with Indian Affairs officials were similarly affected by officials' concerns about their families, their mortgages, and their futures. Richard J. Preston, e-mail to author, 26 April 2004.

21 Burnaby, Nichols, and Toohey, "Final Report," 58.

22 Ibid., 6. 


\section{Going Their Separate Ways, 1980-81}

In mid-September 1980, six months after the completion of the Final Report, Richard Morris, Operations Manager of the Education Council, advised DIAND's Ontario Regional Director of Education Gord Mullin that he had presented the report to his board of directors at a meeting the previous month. The Education Council's board had approved a motion "that the NNLP Report be implemented, and that the NNLP Committee members continue to work cooperatively to ensure the continued implementation of the report in its various aspects." ${ }^{23}$ Noting that this motion signified "approval” of the report, Morris urged Mullin to continue the project: "It is essential now that a final meeting of the NNLP Committee be held as soon as possible to establish the implementation committee. It is the wish of the Board that the Project not be abandoned." He also notified Mullin that the province had agreed to contribute half the cost of translating the Final Report. $^{24}$ The other two Native organizations, Wa-wa-ta Native Communications Society and the Ojibway-Cree Cultural Centre, less formally endorsed the report as well. ${ }^{25}$

During the early 1980s, however, these Native organizations operated on the periphery of policy-making in Ontario. When it came to implementing the Final Report's recommendations, DIAND in particular had little or no interest in their opinions at this time. Marianna Couchie, who had initiated the NNLP and initially championed it within DIAND, became dismayed by the emerging DIAND leadership in Ontario Region and left the federal arena to pursue graduate study. ${ }^{26}$ With her departure, responsibility for the NNLP eventually came to rest with Art Griffith, Mullin's eventual successor as DIAND's Regional Director of Education.

Three months after receiving the Final Report, DIAND officials in Ontario Region included the Native-language program among other agenda items at a meeting of their District Superintendents of Education (DIAND's Education Management Team). At this meeting, held in Kenora in July 1980, two decisions were recorded with respect to Native languages. First, it was decided that DIAND's Ontario Regional office would contact the Ministry "to establish certification/recognized qualifications of Native/Indian Language Teachers," a key recommendation of the Final Report. Second, the District Superintendents of Education were asked to provide Griffith

23 R. Morris to Mullin, 15 Sept. 1980, p. 7 of 185 pp., Access to Information release A-2001-00204 (Northern Native-Languages Project).

24 Ibid.

25 Long, "An Idea Ahead of Its Time.”

26 Ibid.; Marianna Couchie, interview with author, Nipissing reserve, 16 April 2002. 
with suggestions regarding DIAND's Native-language program for the following school year. ${ }^{27}$ The Final Report was not discussed in any depth, and the discussants clearly had no grasp of its details.

At a subsequent Education Management Team meeting held in Peterborough, on October 7-9, 1980, Griffith announced that DIAND would no longer employ a Native-Languages Co-ordinator. (The position of Native-Languages Co-ordinator was created by DIAND Regional Director of Education Gord Mullin in the early 1970s with discretionary funds, so it had always existed at the whim of regional officialdom. Former Native-Language Consultant Mary Mitchell recalls that once, when talking with Mullin about her Native-language program, he responded, "What program?"28) Griffith also gave notice that discussions were "underway with Lakehead University regarding the possibility of taking over the Native Language Programs."29 With the position of Native-Languages Co-ordinator gone, coupled with the devolution of responsibility for Native-language courses to postsecondary institutions, Native languages would soon cease to be an item of day-to-day interest to DIAND regional officials in Ontario. Thereafter, as Jerry Paquette has shown, Native languages were excluded from DIAND's curriculum development efforts in Ontario; Native-language teachers were virtually "left completely to their own devices," with limited support from Native cultural centres. ${ }^{30}$

It was Griffith who drafted Mullin's response to the Education Council regarding its endorsement of the Final Report. Mullin was "surprised at the blanket approval to implement the report in view of the implications for major revisions to both the curriculum and educational delivery mechanisms and the lack of in-depth discussion we have had on these matters.” He informed Morris that no decision had been made about co-funding translation of the Final Report, pending an "internal meeting in mid-October," and asked him to "be assured that native language is one of our program priorities."31 It was a condescending letter, clearly criticizing Morris and the Education Council for endorsing such a complex report in just six months. It also excluded the Education Council (and the two other Native

27 Minutes of a Meeting of the Education Management Team in Kenora, 25-26 June 1980, pp. 2-20 of 149 pp., Access to Information release A-2002-0250 (Education Management Team, Ontario Region, 1979-82).

28 Conversation with author, 8 May 2002, Toronto.

29 Minutes of a Meeting of the Education Management Team in Peterborough, 4-6 Nov. 1980, A-2002-0250, pp. 41-52.

30 Burnaby, Nichols, and Toohey, "Final Report," 32; Paquette, Aboriginal SelfGovernment and Education, 59; Paquette, "Purpose, Parity and Conflict," 123-24.

31 Mullin to R. Morris, 29 Sept. 1980, ATI release A-2001-00204, p. 6. This letter bears code "E-2" and Griffith’s initials. 
organizations) from the mid-October discussion, for the meeting would be an "internal" one.

No records of the internal meeting have survived, although there is a copy of an "urgent" telex, dated October 1, 1980, from DIAND Ontario Regional Director of Education Gord Mullin, but again drafted by Griffith, captioned "NORTHERN NATIVE LANGUAGE REPORT.” It summoned the Superintendent of Education for Sioux Lookout District, Mac Hall, to a meeting on October 21 "TO DISCUSS REPORT AND ESTABLISH DEPARTMENTAL RESPONSE."32 DIAND did not co-fund translation of the Final Report into Cree and Ojibwe, and declined to name a representative to the proposed Steering Committee.

The Algonquian Native-Language Instructors' Program found a permanent home at Lakehead University and so did former DIAND Native-Languages Co-ordinator Mary Mitchell. The program, developed in 1981, has two streams: Native-as-a-First-Language and Native-as-a-Second-Language. ${ }^{33}$ (There are several Native languages spoken in Ontario; Lakehead's program focuses on two of the Algonquian languages, Cree and Ojibway.) But graduates of the NFL stream, so crucial to vernacular-language education, would not be certified as teachers when policy decisions were made two years later.

As we have seen, the Ministry had been prepared to endorse a tripartite Steering Committee involving the Native organizations and DIAND. It had also been willing to share the cost of translation of the final report into Cree and Ojibwe, but without federal funds this never happened. Certifying Native-language teachers and authorizing the teaching of Native languages as subjects in Ontario schools would require major changes in provincial policy and regulations. Deputy Minister Dr. Harry K. Fisher referred the NNLP's Final Report to the Ministry's Native Education Co-ordinating Committee, a permanent forum for Native issues which he had established. ${ }^{34}$ Keith Lickers, who had co-chaired the NNLP, was assigned the lead role in discussing the Final Report's various recommendations with representatives of any branches of the Ministry that might be affected, a process that stretched over the course of two years. ${ }^{35}$ This period of intensive internal study carefully considered the use of Native

32 Mullin to District Superintendent of Education, Sioux Lookout, 1 Oct. 1980, ATI release A-2001-00204, p. 61. This letter also bears the code E-2.

33 Calendar 1982-83 (Thunder Bay: Lakehead University, 1982), 112-14, 211-13; Mary Mitchell, "Algonquian Language Education,” in Actes du Dix-Septième Congrés des Algonquinistes, ed. William Cowan (Ottawa: Carleton University Press, 1986), 209-14.

34 Keith Lickers, “Ontario,” in Recent Developments in Native Education (Toronto: Canadian Education Association, 1984), 39-40.

35 Keith Lickers, interview with author, Toronto, 7 May 2002. 
languages both as subjects of instruction and as languages of instruction, a direction set in motion by Dr. Bette Stephenson, then Ontario's Minister of Education. ${ }^{36}$ She had been intrigued by one of Lickers' briefings on the NNLP and had signalled her full support as officials in the various branches of her Ministry (Legal, Business and Finance, Teacher Education, Curriculum, and Curriculum Services) co-ordinated their efforts, weighing implications and discussing the pedagogical merits of various policy changes arising from the NNLP.

Ministry officials were able to proceed much more quickly, in cooperation with DIAND, in responding to the NNLP's ESL recommendations, for this would simply extend an existing policy to Native students. ESL methods and materials had been in common usage in Toronto by teachers of immigrant students since the 1950s. ${ }^{37}$ And in the federal jurisdiction, the Hawthorn researchers had stressed the need for ESL for Indian students two decades earlier. ${ }^{38}$ In 1981-82 the Ministry and DIAND began advancing funds to the Ontario Institute for Studies in Education for what would become a milliondollar six-year project known officially as "Reading in English for Native Children.” Better known as the Circle Program, it produced culturally appropriate ESL materials for Native students in the primary grades. $^{39}$

\section{Comparing Notes, 1982-83}

Given DIAND's rejection of a Steering Committee, the three Native organizations were now excluded from the formal policymaking process. But support for the NNLP was received from another quarter, in September of 1982, when the Native Languages Advisory Committee decided that the NNLP report "adequately represents language programs throughout the [Ontario] region,” accepted the report "in principle, and agreed to use it as a working paper from which to develop...long-range plans." ${ }^{\circ 0}$ The Native-Languages Advisory Committee, established by DIAND's former NativeLanguages Co-ordinator, Mary Mitchell, had at best an advisory role; its advice had little or no impact on DIAND programs. ${ }^{41}$

\footnotetext{
36 Stephenson was concurrently Minister of Colleges and Universities.

Fleming, Schools, Pupils, and Teachers, 150.

Harry B. Hawthorn et al., A Survey of the Contemporary Indians of Canada: Economic, Political, Educational Needs and Policies. Volume II, October 1967 (Ottawa: Queen's Printer, 1968), 12.

39 Burnaby, Circle.

40 Barbara Burnaby, Aboriginal Languages in Ontario (Toronto: Ministry of Education and Ministry of Colleges and Universities, 1984), Appendix B.

41 Ibid., 26.
} 
Following two years of review by her officials, Dr. Stephenson directed Keith Lickers to prepare a Cabinet submission in support of Native languages as subjects of instruction and as languages of instruction, as well as the certification for Native-language teachers. Lickers recalls that the Minister went through this draft Cabinet submission "with a fine tooth comb.” In September of 1982, she asked Lickers to ascertain DIAND's position. In a letter to DIAND's Art Griffith, Lickers acknowledged DIAND's accomplishments in the field of Native languages and prior federal-provincial co-operation. He advised Griffith that Ontario was now ready to proceed "in an effective and coordinated way with respect to Native language educational programs, the training of personnel and the production of education materials," and asked to meet with Griffith and his staff "as we attempt to address the linguistic and educational needs of Native students in Ontario schools.”42

This meeting, which took place on 11 October 1982, seems to have focused not on the Ministry's plans but on DIAND's response to the NNLP. The following day, in a letter drafted by Griffith, Mullin notified Lickers that DIAND had "not accepted the report and its recommendations as policy. While several individual recommendations have been accepted, the report in total has not and in all likelihood will not become official Department position.” DIAND's Ontario Regional Office had decided to "stimulate academic interest" in Native languages; it would support one centre for the study of Algonquian languages, like Ojibwe and Cree, and another for the Iroquoian languages. ${ }^{43}$ Mullin hoped that the "establishment of centres for language development and native language teacher training [would] promote an Indian controlled academically sound direction for developments in the field of Native Languages." 44

Lickers and his DIAND counterparts apparently met a second time, four months later, when Lickers revealed his Minister's full intentions, circulated a "Discussion Paper on Potential Native Language Policy,” and requested a response within a week's time. Lickers remembered the meeting vividly, two decades later. According to him, Griffith chuckled, in his characteristic way, and replied, "You have to be kidding." He informed Lickers that DIAND was not prepared to support vernacular education. There would be "lots of

42 Letter to Art Griffith, 19 Sept. 1982, ATI release A-2001-00204, p. 4.

43 Lakehead University focuses on Ojibwe and Cree. The Iroquoian languages are Mohawk, Cayuga, Seneca, Onondaga, Tuscarora, and Oneida. See Burnaby, Aboriginal Languages in Ontario, and John Stanley, Aboriginal Language Standardisation Project: Progress Report (Toronto: Ontario Training and Adjustment Board, 1996).

44 Mullin to Lickers, 12 Oct. 1982 (emphasis in original), pp. 745-46 of 1,018 pp., ATI release A-2002-00253 (Correspondence of the Regional Director of Education, Ontario Region, 1978-79 through 1982-83). 
support” from DIAND, however, for moving forward in tandem on the certification of Native-language teachers, and on developing a policy for Native languages as subjects of instruction. ${ }^{45}$ In a letter to Lickers dated 8 February 1983, DIAND Superintendent of Operations Gary Maxwell signed a letter on behalf of Mullin, but drafted by Griffith, responding to the Discussion Paper and this more recent meeting with Lickers. He thanked Lickers for the invitation to review the document, asserting that DIAND's "involvement in this policy development [is] a prerequisite for successful implementation." "It would be prudent," he wrote, "that our mutual efforts be consistent with the wishes of Indian people and that options presented to Bands are both achievable and realistic." Maxwell expressed "serious and significant concerns" and announced that regional officials were "not prepared to endorse" the Ministry's position "in its present form.” They were preparing a response, on the understanding that the Discussion Paper had not yet been presented to "senior management" within the Ministry (i.e. to Deputy Minister Fisher). Maxwell requested additional time so that DIAND could "consult with appropriate groups representing native people" and advance their concerns at "a more appropriate level between our [governments]." 46

Lickers analyzed the situation as a civil servant. He suspected that Griffith viewed his Minister's intentions as provincial intrusion into an area of federal jurisdiction, with a hidden agenda of embarrassing the federal government. ${ }^{47}$ Griffith recalled that jurisdiction was "not an issue" and there was no concern over embarrassment. ${ }^{48} \mathrm{~A}$ former colleague confirmed that "Art never got embarrassed." It was Stephenson and her government who would be embarrassed if the Cabinet submission was not handled properly.

Lickers was not surprised by DIAND's rejection of vernacularlanguage education. He recalled: "Never, in all my experience in dealing with the federal government, were they ever in the game. Their agenda has always been assimilation and they have never supported Aboriginal culture and language issues.” Keith Lickers' mother was an Ojibwe and his father was a Mohawk, the first Indian lawyer in Canada. Although Lickers speaks neither language, he was keenly aware of the importance of Native language to a Native child's self-concept. So he was personally “appalled” by Griffith's response

45 Lickers interview, 7 May 2002.

46 Maxwell to Lickers, 8 Feb. 1983, pages 820-1 in 353 pp,. ATI release A-200200256 (Correspondence of District Superintendent of Education, Sioux Lookout, 1978-79 to 1981-82). This letter bears the code E-2.

$47 \quad$ Lickers interview, 7 May 2002.

48 Griffith, telephone interview with author, 20 Nov. 2002. 
to his Minister's position, knowing it would have an adverse impact on Native students. ${ }^{49}$

Lickers reported the results of this meeting to the Minister, since they were so close to finalizing the Cabinet submission. As a career civil servant, Lickers' prime concerns would have been not embarrassing his Minister, and not letting her intrude, or incur financial obligations, without warning, in an area of federal jurisdiction. He recalls that he told Stephenson, "It looks like we can only go with one," and that her response was, "Go for it."50 This was a momentous decision, made in mere seconds, but without DIAND support and funding the Minister would have been unable to garner Cabinet support, from a Conservative government, for vernacularlanguage education. (In correspondence concerning a concurrent disagreement, DIAND had stressed the cost implications of any unilateral Ministry initiative..$^{51}$ ) Gradual policy change was usually an easier sell. $^{52}$

Lickers revised the Native-languages Cabinet submission, dropping any reference to their use as languages of instruction. Ministry legal advisors had already cautioned Stephenson about changing the Ontario Education Act's reference to English and French as the primary languages of instruction. ${ }^{53}$ The revised Cabinet submission was approved in 1985, as the Conservative regime was replaced by a Liberal government. ${ }^{54}$ Lickers feels that Stephenson later regretted her decision to exclude Native languages as languages of instruction; he feels it could have made a real difference in schools under provincial jurisdiction, in Summer Beaver, Moosonee, Mine Centre, and Lac La Croix. ${ }^{55}$

\section{Policy Considerations}

At the community level, most northern Ontario Native people still existed in what one of the NNLP researchers, Kelleen Toohey, characterized as a colonial position: "with regard to schooling policy,

\footnotetext{
49 Lickers interview, 7 May 2002.

Ibid.

51 "I assume that any policies thus approved in isolation from the Department will be totally supported from Ministry resources.” Mullin to Lickers, 11 April 1983, ATI release A-2002-00253, p. 883. This letter bears the code E-2.

52 Cartwright, "French-language Services in Ontario: a policy of 'overly prudent gradualism'?” 273-99.

53 Ontario Statutes, Education Act, s. 264(1)(f).

54 Rosemary Spiers, Out of the Blue: The Fall of the Tory Dynasty in Ontario (Toronto: Macmillan of Canada, 1986).

55 Lickers e-mail, 1 Nov. 2002.
} 
budgeting, hiring and firing of teachers, goal-setting and curriculum, non-Native people, many of whom are either non-residents or generally transient residents, make decisions. ${ }^{, 56}$ In the 1970s the Cree and Ojibwe of northern Ontario had created organizations like the Education Council and the Ojibway-Cree Cultural Centre. These organizations had some interest in revitalizing Native languages, but had no authority when it came to Native education and were dependent on DIAND funding.

If Ontario’s Minister of Education made a pragmatic decision not to risk additional political capital on vernacular-language education, she did so on the advice of a trusted Native advisor, knowing that her officials had signalled her willingness to translate the Final Report of the Northern Native-Languages Project into Cree and Ojibwe, and to join the northern Native organizations on a Steering Committee. The advantages and disadvantages and implications of vernacular education had been carefully weighed by her officials, in what we might today call a fairly open and rational, but complex and timeconsuming process. ${ }^{57}$ The Minister may also have toyed with the notion of developing a Native-education policy independent of DIAND.

In the early 1970s, DIAND regional officials had worked closely with Ministry personnel to develop People of Native Ancestry (PONA), a curriculum resource guide. DIAND had "shared the production costs" of this document, intended for use "in the schools that are under that Department's jurisdiction as well as in the publicly supported schools of the Province of Ontario."58 PONA was not Ministry policy, but it lent some strong support to vernacular-language education. By early 1983, DIAND officials were worried that the Ministry had excluded DIAND from its review of the impact of PONA on provincial school boards. DIAND Regional Director of Education Gord Mullin went over Keith Lickers' head and appealed to his old classmate from Stratford Normal School, Deputy Minister of Education Harry K. Fisher. Mullin expressed a "growing concern” that the PONA review would form the basis for Ministry policy, directly affecting the 7,000 Department-sponsored Indian students attending schools under provincial jurisdiction, and, indirectly, the DIAND schools, which were expected to follow the provincial curriculum. He

56 Kelleen Toohey, "Northern Native Canadian Second Language Education: A Case Study of Fort Albany, Ontario” (Ph.D. diss., University of Toronto, 1982), 225-26.

57 Ron Common, "An Analysis of Ministry of Education Policy-Making Structures, Committees and Procedures," in his New Forces on Educational Policy-Making in Canada (St. Catharines: Brock University, 1985), 11-28.

58 People of Native Ancestry: A Resource Guide for the Primary and Junior Divisions Toronto: Ministry of Education, 1975), i, 28. See also Report of the Task Force on the Educational Needs of Native People (Toronto: Queen's Printer, 1976). 
urged his old friend to reconsider the decision to exclude DIAND from the review. ${ }^{59}$

It was a circular, self-serving argument. DIAND officials wanted their schools to follow Ministry policy, but they didn't want that policy to promote vernacular-language education. In the end, the Minister of Education allowed DIAND to dictate provincial policy. ${ }^{60}$ The Report of the Royal Commission on Aboriginal Peoples stated that "changes in the public school system have been incremental and far too slow." ${ }^{61}$ But this case study of the NNLP shows that sometimes it was DIAND officials who wanted to proceed more slowly than their provincial counterparts.

The DIAND policy-making process at the regional level was very secretive in the 1980s. Authority in program matters rested with regional officials, for their superiors in Ottawa had "little or no interest in program activities." "62 Ontario Regional Director of Education Gord Mullin, then about 60 years old, was nearing retirement. His three Regional Superintendents (Donnelly, Griffith, and Maxwell) had started their careers with DIAND in northwestern Ontario, where they were known as the "Sioux Lookout mafia." The trio now lived in Oakville and carpooled together to the Toronto regional office. By 1982 one of these three was involved in all "briefings and key negotiations. Gord was a figurehead by then." 63 In matters relating to the NNLP, in particular, Art Griffith's role “was absolutely key and he was never in support of N[ative as a] F[irst] L[anguage]." ${ }^{64}$ Griffith contends that his decisions were supported by Donnelly and Maxwell. ${ }^{65}$ Donnelly concedes that "strong views existed on topics but once the three of us hashed things out we had consensus on course of action." 66

59 Mullin to Fisher, 21 Jan. 1983, re Native Education Review, ATI A-2002-00256, p. 815. It bears the code E-2 and Griffith's initials.

60 Given the division of powers at Confederation, provinces were loath to unilaterally adopt legislation “singling out” Indians; see James C. MacPherson, MacPherson Report on Tradition and Education: Towards a Vision of our Future (Ottawa: DIAND, 1991), 25-28.

61 Report of the Royal Commission on Aboriginal Peoples, Volume 5. Renewal: a twenty-year commitment (Ottawa: Canada Communication Group, 1996), 443. Similarly, Jerald Paquette cautions against leaving Native "educational decision making” to "provincial Ministries of Education which represent the interests of a population only a minuscule percentage of which is aboriginal"; see his "Policy, Power and Purpose: Lessons from Two Indian Education Scenarios,” Journal of Canadian Studies 24, 2 (1989): 92.

62 John Donnelly, interview with author, 17 May 2002, Toronto; e-mail to author, 18 June 2002.

63 Donnelly interview, 17 May 2002.

64 Donnelly e-mail,18 June 2002.

65 Griffith, e-mail to author, 20 June 2003.

66 Donnelly, e-mail to author, 22 June 2003. 
In defending his stance on vernacular-language education, Griffith identified four specific considerations: community opinion, limited resources, national policy, and program priorities: "I totally disagree that the decision not to endorse the NNLP might constitute a breach of [fiduciary] duty on the part of the Crown. In fact, a case could be made that to endorse immersion programming without the clear direction from First Nations to do so, without the resources to develop required curriculum, without trained teachers to teach immersion, and without any national policy direction to do so - that may have been a breach of [fiduciary] duty by taking away any reasonable chance that First Nation students may have had to compete and complete secondary school., ${ }^{, 67}$

\section{Community Opinion}

Griffith seems to have believed that Native-language shift was irreversible. From his brief experience in northern Ontario schools, he recalled that northern students were increasingly "not talking in the Native language, but using English." ${ }^{68} \mathrm{He}$ felt that northern communities' primary concern was the acquisition of English, and the best way for them to acquire it was not through vernacular-language education: "Language was and is important, however most First Nations wanted their children leaving the federal school elementary system with the skills and abilities to be successful at the secondary school level. I think an [analysis] of the direction that communities wanted the department to move would have been helpful." ${ }^{69}$ Of course when northern communities took over the operation of DIAND's English-immersion schools, most perpetuated the only model they knew. Curiously, Griffith cites this as evidence that in the 1980s he had carried out their wishes in regard to vernacular-language education: "The evidence in this regard is clear - when First Nations took over control - what was their focus?"70

Griffith's contention that northern communities had no interest in vernacular-language education is suspect when we learn the steps that he took to suppress the NNLP's Final Report. In February of 1983, NNLP lead researcher Barbara Burnaby asked Griffith for permission to make the Final Report accessible to scholars. ${ }^{71}$ Griffith denied her request, arguing that "the Regional Office staff have many cumulative

Griffith e-mail, 20 June 2003.

Griffith interview, 20 Nov. 2002.

Griffith e-mail, 20 June 2003.

Ibid.

Letter dated 11 Feb. 1983, ATI release A-2001-00204, p. 3. 
years of experience in working with Indian people and we do not agree that this report and its recommendations will prove to be the panacea for the Native Language Program that you and others envision...We feel that to include the report on the ERIC document file would result in another argument for the implementation of this report in our program. This we are not prepared to do.” He also warned her to stop mentioning the NNLP publicly: "[future] reference to this report in the press, letters to the Ministry of Education, extrapolating of rationale to other Department projects (i.e. Reading in English for Native Children [the Circle Program]) can only be interpreted as an effort to promote 'de facto' implementation of the report and its recommendations." "72

Griffith clearly wanted to ensure that northern communities never had an opportunity to consider other models of education during his watch, particularly any culturally conservative Indian leaders. And there was a personal edge to all of this: he wanted to silence Barbara Burnaby, vernacular-language education's principal advocate; she "rubbed [him] the wrong way" and was "negatively viewed by some" in the Regional Office. ${ }^{73}$ The Final Report of the NNLP, in contrast, sought to empower Native communities to make their own decisions about the roles of languages in education, something the NNLP researchers viewed as being owed to those communities, a "moral responsibility." 74

Representatives of the three Native organizations were likely unaware of all of Griffith's actions. They undoubtedly supported the notion of developing more relevant ESL materials, but may have felt that this should be their role. They agreed that Native-language teachers needed recognition and support, and endorsed the development of a curriculum guide for Native languages. They may, however, have opposed or had different views regarding vernacularlanguage education. They certainly had an interest in Ontario Region's scarce discretionary funds, and may sometimes have viewed the NNLP researchers as unwelcome competitors. Community opinions concerning vernacular-language education were undoubtedly divided, and any Indian teacher who promoted it was told to employ English in the classroom. ${ }^{75}$

72 Griffith to Burnaby, 24 Feb. 1983, ATI release A-2001-00204, pp. 1-2. Burnaby continued to refer to the NNLP in her publications (see note 122 below). She also deposited the Interim and Final Reports of the NNLP in the Ontario Institute for Studies in Education library.

Donnelly interview, 17 May 2002; e-mail, 18 June 2002.

Burnaby, Nichols, and Toohey, "Final Report," 14.

Long, "An Idea Ahead of Its Time." 


\section{Limited Resources}

Griffith recalls that "there was no meaningful political will [in Ottawa]," and his former colleague Donnelly confirmed that Griffith "realized there were no resources and no political will.", "With a recession in the early 1980s and a ballooning federal budget deficit, these were challenging times for Canada's central government. ${ }^{77}$ DIAND's Annual Report for 1982-83 noted that the outlook for the future was "Doing more with less." ${ }^{\text {"78 }}$ In 1984 Brian Mulroney's Conservative government would usher in a new era of cost-cutting, deficit reduction, and musing about terminating the rights and privileges of Indians. ${ }^{79}$ Griffith had a skeletal staff of four to support him in supervising DIAND's ten far-flung districts in Ontario. One education officer was responsible for elementary and secondary education and directly supervised two schools. Another, assigned to post-secondary education, supervised two urban counselling units. There was also a computer consultant and a database consultant. Griffith could have either a computer consultant or a Native-language consultant, not both. The regional office had a lot of clerks and secretaries, but it had no curriculum experts, and certainly no specialists in bilingual/bicultural education. ${ }^{00}$

Fred Hunter, then a DIAND District Manager and now recently retired as a senior Cree official in DIAND headquarters, observes that Griffith had little flexibility in realigning his limited resources: "Budgetary constraints probably played a huge role, as most Regions had very little discretionary budgets, discretionary meaning funds left over after hard commitments were taken into account. For example, I expect that salaries (in a unionized environment), energy costs, [and] maintenance of existing facilities, were a huge fixed cost leaving little real discretionary funding.",81

76 Griffith interview, 20 Nov. 2002; Donnelly e-mail, 18 June 2002.

77 Alan A. Maslove, "The Public Pursuit of Private Interests," in his How Ottawa Spends 1985: Sharing the Pie (Toronto: Methuen, 1985), 1-29.

78 Annual Report 1982-1983 (Ottawa: DIAND, 1983), 27.

79 Katherine Graham, "Indian Policy and the Tories: Cleaning Up After the Buffalo Jump,” in How Ottawa Spends 1987-88: Restraining the State, ed. Michael J. Prince (Toronto: Methuen, 1987), 237-67; Murray Angus, And The Last Shall Be First: Native Policy in an Era of Cutbacks (Toronto: NC Press, 1991); Walter Rudnicki, "The Politics of Aggression: Indian Termination in the 1980s," Native Studies Review 3, 1 (1987): 81-93.

80 Gary Maxwell, Regional Superintendent of Program Resources, had one Education Officer responsible for "Review and Analysis," and one who handled "Special Projects." John Donnelly, Regional Superintendent of Community Education, had a single Education Officer and one consultant. ATI release A-2002-0250, pp. 63-66.

81 E-mail to author, 3 July 2003. 
As already noted, without additional resources it would have been an enormous challenge for Griffith to support vernacular-language education, which he confuses with "immersion," in Ontario in the 1980s. He recalls that "there were no materials for immersion, no appropriate materials," and "the number of Aboriginal languages in Ontario" was a further deterrent in his mind. ${ }^{82}$ His former colleague Donnelly confirms that the "view was [that] resources both human and material were not available to support such a program." ${ }^{83}$ Griffith and his colleagues could, and did, choose to introduce a very limited Special Education program in Ontario Region; yet experts on Native education stress that language issues need to be resolved before addressing special education issues. ${ }^{84}$ By largely ignoring the mismatch between northern Native students' first language and the language of schooling, DIAND's emphasis on Special Education kept Native education in a "learner deficit" and "subtractive bilingualism" paradigm. ${ }^{85}$

The crisis orientation of DIAND's Regional Office meant that scarce human resources could not be assigned to complex ongoing projects. Gord Mullin recalled that in those days DIAND employees had a saying: "When the phone rings, be prepared to go anywhere on short notice." He used to joke that his red Volkswagen convertible should "go down in history" for all the Indian reserves it had visited. When I mentioned Larry Sands' recollection that much of the job was "putting out fires," Mullin replied, "That's true”; it was "a big job” and "a lot of hard work." ${ }^{\circ 6}$ John Donnelly observed that there were always twenty or thirty "pots boiling away," serious problems that demanded regional administrators' immediate attention and probably seemed much easier to understand and implement than vernacularlanguage education. ${ }^{87}$

\section{National Policy}

Former DIAND officials in the Ontario Region contend that DIAND "policy" was made at headquarters in Ottawa; the regional offices simply "interpreted policy" and then "issued directives" to

\footnotetext{
82 Griffith interview, 20 Nov. 2002.

83 Donnelly e-mail, 18 June 2002.

84 Annual Report 1984-1985 (Ottawa: DIAND, 1985), 47.

85 Jim Cummins, "The Empowerment of Indian Students," in Teaching American Indian Students, ed. Jon Reyhner (Norman: University of Oklahoma Press, 1992), 3-12. See also Cummins' Bilingualism and Special Education: Issues in Assessment and Pedagogy (San Diego: College-Hill Press, 1984).

86 Mullin, telephone interview with author, 16 Oct. 2002.

87 Donnelly interview, 17 May 2002.
} 
their districts. ${ }^{88}$ But what exactly was the policy that would guide DIAND officials in Ontario when it came to Native languages?

DIAND's 1978 Education Policy Program Circular E-1 stated that "the language of instruction shall be either English or French, but provisions may be made in lower grades for some instruction in a local native language." ${ }^{89}$ And DIAND's Circular E-5 supported vernacularlanguage education for at least the first four years of school. ${ }^{90}$ Indian Affairs headquarters published materials promoting bilingual education for Native students, but cautioned that "not all Native people are in favour of Native language instruction in the schools, and such programs are only instituted with their approval and support."91 While the 1972 National Indian Brotherhood manifesto, Indian Control of Indian Education, clearly supported the transitional use of Aboriginal languages, the entire document had not been adopted as DIAND policy. ${ }^{92}$ Jean Chrétien, then Minister of Indian Affairs, had adopted only two basic principles of the Brotherhood's proposal, but these carried considerable weight. ${ }^{93}$ This position was clearly spelled out in Indian Affairs' 1978 Circular E-1: “the general principles of (a) parental responsibility and (b) local control as outlined in the National Indian Brotherhood policy paper 'Indian Control of Indian Education' shall be followed wherever practical and desirable." 94

Although policy was acknowledged to come from headquarters, headquarters was also perceived by regional officials as "ineffective" when it came to program issues and, by the mid-1980s, Ottawa officials were viewed as mere "caretakers." 95 Policy circulars developed unilaterally by DIAND were rejected by Indian leaders. ${ }^{96}$

\footnotetext{
88 Ibid.

89 Linda Tschanz, Native Languages and Government Policy: An Historical Examination (London, ON: University of Western Ontario, 1980), 20.

90 Margaret S. Ward, "Indian Education in Canada: Implementation of Educational Policy, 1973-1978” (M.Ed. thesis, University of Saskatchewan, 1988), 206-7.

91 Indian Education: Native Bilingual-Bicultural Education Programs (Ottawa: DIAND, 1976) is a reprint of Ida Wasacase, "Native Bilingual-Bicultural Education Programs," Dialogue 3, 1 (1976); Opikawak: They Grow Up (Ottawa: DIAND, 1976), 24.

92 Indian Control of Indian Education (Ottawa: National Indian Brotherhood, 1972), 15.

93 Ward, "Implementation," and her "Indian Education: Policy and Politics 19721982," Canadian Journal of Native Education 13, 2 (1986): 10-21.

94 Tschantz, Native Languages and Government Policy, 20 (emphasis added).

95 Donnelly interview, 17 May 2002.

96 Ward, "Indian Education in Canada.” Donnelly states that only Circular E-12 was actually in force; Donnelly e-mail, 20 June 2002.
} 


\section{Program Priorities}

Any resources allocated to vernacular-language education would not be available for other initiatives. One of Griffith's goals was to ensure that the department's schools kept up with, or even ahead of, Ontario schools on the computer technology curve, and that students stayed in school longer. "We did spend a significant amount of time strategizing about how to move forward in Native education," he states. "Our focus was putting computers in the schools, and we were 18-24 months ahead of the province" in this initiative. A more fundamental issue facing Indian Affairs education officials in Ontario at this time, as Griffith remembers it, was that Indian students were "behind in core achievement levels." " $\mathrm{He}$ is remembered for emphasizing that students needed more "time on task." ${ }^{\text {" }}$ Underlying these program choices, the dilemma for DIAND administrators was, "How were we going to move forward on meaningful curriculum development?” The choice, as Griffith saw it, was, “Are we going to gear up and run the schools [e.g., in a culturally relevant manner], or devolve them to local control?"

Griffith's endorsement of ESL material development meant that he had no resources left for vernacular-language instruction. His former colleague Donnelly observed, "importance attached to ESL led to Circle program and emphasis on adapting [curriculum]; native language programming enhanced; lost opportunity for $\mathrm{N}$ [ative as a] F[irst] L[anguage].”100

Planning became increasingly "centralized" following the Auditor-General's report of $1980 .^{101}$ Nationally, the Department's "main objective" was to improve the retention and graduation rate of Indian students from secondary schools. ${ }^{102}$ Regional managers were expected to formulate measurable goals. Ontario Region's Operating Goals for the period 1982-86 were: to increase the number of student weeks in post-secondary programs from 40,000 to 60,000 ; reduce the number of substandard educational facilities on reserves from 23 to 10 ; increase the number of grade 12 students from 477 to $1,000 .{ }^{103} \mathrm{It}$

97 Griffith interview, 20 Nov. 2002.

98 Donnelly interview, 17 May 2002.

99 Griffith interview, 20 Nov. 2002.

100 Donnelly e-mail, 18 June 2002.

101 Paquette, "Policy, Power, and Purpose: Lessons from Two Indian Education Scenarios," 86; Report of the Auditor General, 171-77.

102 Annual Report 1978-79 (Ottawa: DIAND, 1979), 28; Annual Report 1979-1980 (Ottawa: DIAND, 1980), 14; Annual Report 1980-81 (Ottawa: DIAND, 1981), 23; Annual Report 1981-82 (Ottawa: DIAND, 1982), 42.

103 Mullin to Regional Coordinator Operating Plans Ontario Region, 21 Aug. 1980, re Regional Operating Goals for 1982-1986, ATI A-2002-00253, p. 477. 
was easier to measure the number of microcomputers in the schools or the number of Indian students attending a career fair than the vitality of Native languages and the effects of vernacular-language education on student achievement. DIAND simply reported the number of Indian students receiving "native language instruction in one form or another." 104

Regional Operating Goals were expected to be consistent with the overall goals for DIAND approved by Parliament, and were presumably rubber-stamped by DIAND officials in Ottawa headquarters. There were nine "Blue Book" goals attached to DIAND's spending estimates in 1982-83, two of which are especially relevant here: "To assist and support Indians and Inuit in having access to educational programs and services which are responsive to their needs and aspirations, consistent with the concept of Indian control of education," and "To assist and support the Indian and Inuit peoples in preserving, developing and expressing their cultural identity, with emphasis upon their native languages."105 But what were Indians' "needs and aspirations"? The Auditor-General had observed that DIAND managers did not have "a common interpretation of what the Department's role was" and this was "most evident in the stance that managers believed the Department should take in respect to the demands of native people.” With "no uniform planning process," the "exercise of control depended on the style of individual managers."106

The federal Indian Act gave DIAND officials the authority to make unilateral decisions with relative impunity. Indians certainly could and did resist but, even for organizations like the Education Council or the Ojibway-Cree Cultural Centre, this was generally a

104 Annual Report 1982-1983 (Ottawa: DIAND, 1983), 27; Annual Report 1984-1985 (Ottawa: DIAND, 1985), 48. There were 30,000 students receiving Native-language instruction according to Annual Report 1979-1980 (Ottawa: DIAND, 1980), 11.

105 Canada, Department of Finance, Estimates for the Fiscal Year Ending March 31, 1980, vol. 12, Indian Affairs and Northern Development (Ottawa: Supply and Services Canada, 1979), 16; the wording is unchanged through 1982-83. Strictly speaking, the "Blue Book" refers to Part II of the Estimates. Part I is a general overview of government spending, while Part III contains detailed information from individual departments, such as DIAND, and federal agencies; see Canada, Department of Finance, Estimates for the Fiscal Year Ending March 31, 1997 (Ottawa: Supply and Services Canada), 6, and Bruce Curtis, "The Canada 'Blue Books' and the Administrative Capacity of the Canadian State, 1822-67," Canadian Historical Review 74, 4 (Dec. 1993): 535-65.

106 Report of the Auditor General of Canada to the House of Commons. Fiscal Year Ended 31 March 1980 (Hull: Supply and Services Canada, 1980), 171-77. 
time of wardship and tutelage, of "soliloquy," not dialogue. ${ }^{107}$ As the Hawthorn researchers had discovered, two decades earlier, DIAND officials often felt that they, by virtue of their field experience, "were in touch with certain 'mysteries' which outsiders could not comprehend.” These “outsiders" included academic researchers like the NNLP researchers, and even Indians themselves, "by virtue of their dependent status." 108 DIAND regional officials sometimes worked with their provincial counterparts, but felt unconstrained by the outcomes of such joint ventures, as we saw with the NNLP and the People of Native Ancestry document, when it came to vernacularlanguage education. Ultimately, Griffith and his colleagues seem to have assumed that they and their hand-picked "representative" or "progressive" Indians "knew better than reserve residents what the band's real interests were," a fundamental principle of tutelage. ${ }^{109}$

\section{Policy Decisions}

The more obvious policy decisions, approved by the provincial Cabinet, were to certify Native-language teachers and develop a curriculum guideline for Native languages. The Teacher Qualifications regulation, under Ontario's Education Act, was amended to accommodate the certification of Native-language teachers (such as graduates of the Lakehead Native-as-a-Second-Language program). ${ }^{110}$ This professionalized Native-language teachers, who no longer needed first to be certified to teach all subjects in English. They would no longer be referred to as mere "instructors" who were "unqualified," and their positions would no longer have to be re-advertised year after year.

Native Languages 1987 was the province's first provincial curriculum guideline for teaching a Native language "as a second language.” Keith Lickers served as the Ministry’s Project Manager, and Marianna Couchie (who was by then a Ministry education official)

107 Noel Dyck, What is the Indian "Problem"?: Tutelage and Resistance in Canadian Indian Administration (St. John's: Memorial University of Newfoundland, 1991); Adrian Tanner, "Introduction: Canadian Indians and the Problem of Dependency," in his The Politics of Indianness: Case Studies of Native Ethnopolitics in Canada (St. John's: Memorial University of Newfoundland, 1983); Graham, Public Policy and Aboriginal Peoples.

108 Harry B. Hawthorn, H.A.C. Cairns, S.M. Jamieson, and K. Lysyk, A Survey of the Contemporary Indians of Canada: A Report on Economic, Political, Educational Needs and Policies, Vol. 1 (Ottawa: Queen's Printer, 1967), 369-70.

109 Hawthorn et al., A Survey of the Contemporary Indians of Canada, Vol. 2 , 195-97; Dyck, What is the Indian Problem?, 134-35.

110 Now Ontario Regulation 184/97, amended to O. Reg. 373/1 Teacher Qualifications under the Ontario College of Teachers Act, 1996. 
as its Project Leader. ${ }^{111}$ As with the 1975 People of Native Ancestry resource guide, DIAND provided "support and co-operation" and "shared the production costs of this guideline." ${ }^{112}$ Ontario's financial regulations were revised so that schools under provincial jurisdiction would now have access to secure funding for the Native-language program.

It may be less obvious that another policy decision was made: not to extend vernacular education to the Native peoples of Ontario. The second policy decision was made by Art Griffith for Canada and subsequently endorsed by Dr. Bette Stephenson for Ontario. For those who argue that this was not a policy decision, Peter Aucoin's definition of the field of public policy is useful for this study, for it focuses on actions as well as intentions, and on decisions made or not made:

Public policy should not be restricted in its meaning either to the stated "objectives" of a government or the formal "strategies" devised by a government to pursue its objectives. Rather, public policy must be considered to encompass the actual activities undertaken by a government, whether or not a government's objectives and strategies are explicit, or are congruent with its activities....[I]t...must also include the impacts which result either from a government's actions or from a lack of same. The logical justification for this inclusion is that governing is essentially the continual choice between preserving or altering the status quo (or particular conditions thereof) and therefore governments must accept responsibility for the extent to which their actions affect the status quo. ${ }^{113}$

During the 1970s and 1980s, DIAND schools and schools under provincial jurisdiction serving Native children in northern Ontario were premised on a learning-deficit model. ${ }^{114}$ Policy-makers were

111 Native Languages 1987, Part A: Policy and Program Considerations (Toronto: Ontario Ministry of Education, 1987) - now The Ontario Curriculum, Grades 1-8: Native Languages 2001 (Toronto: Ministry of Education, 2001).

112 Native Languages 1987, 87.

113 "Public Policy: Theory and Analysis," in Public Policy in Canada: Organization, Process, and Management, ed. G. Bruce Doern and Peter Aucoin (Toronto: Macmillan of Canada, 1979), 2-3.

114 The deficit model was by no means a new paradigm, nor was it static; see Barbara Burnaby, "Roles of Languages in Education for Native Children in Ontario" (Ph.D. diss, University of Toronto, 1979), and Tschanz, Native Languages and Government Policy. Indeed, DIAND educators had begun to recognize the influence of social and cultural factors and the importance of students' self-esteem; Paquette, "Purpose, Parity and Conflict," 51-70. For example, counsellors provided assistance to Indian students, and the People of Native Ancestry resource document had been developed; these correspond to 
aware that many northern Native students experienced difficulties with school achievement, but attributed these learning problems to an English deficit; their solution was subtractive bilingualism immersing the students in English. ${ }^{115}$ The NNLP researchers had observed that "in most communities...the children come to school speaking all or mainly the Native language. Almost all everyday communication is in the Native language." ${ }^{116}$ Unlike DIAND policymakers, the researchers considered northern Native students' learning difficulties to be rooted in mother-tongue deprivation, a mismatch between the students' first language and the language of school. ${ }^{117}$ They recognized that the Native languages were threatened and that many of the northern communities were in the early stages of language shift. ${ }^{118}$ Moving beyond the deficit model in northern Ontario would have required a paradigm shift in national policy (or a modern land claims agreement), redefining the root of the problem as "mothertongue deprivation" or "(premature) loss" of the students' mother tongue. ${ }^{119}$ Such a shift in DIAND policy could have resulted in real support for Native languages as the initial language of school instruction, but this would not happen in most of Canada in the 1980s. ${ }^{120}$ The NNLP recommendations regarding vernacular-language

Stacy Churchill's Stages 2 and 3 respectively. Similarly, the Circle Program ESL materials confirmed a Stage 3 paradigm. See Churchill, The Education of Linguistic and Cultural Minorities in the OECD Countries (San Diego: College-Hill Press, 1986), esp. 54.

115 Jim Cummins, Empowering Minority Students (Sacramento: California Association for Bilingual Education, 1989), 36-37. See also John Reyhner, “Bilingual Education,” in his Teaching American Indian Students (Norman: University of Oklahoma Press, 1992), 64-66.

116 Burnaby, Nichols, and Toohey, Final Report, 7.

117 Cummins, Empowering Minority Students, 36-37.

118 Barbara Burnaby, "Language Shift in Northern Ontario," in Papers of the 12th Algonquian Conference, ed. William Cowan (Ottawa: Carleton University, 1981), 114-20. 119 Vernacular transition is Churchill's Stage 4. Colin Baker and Sylvia Prys Jones refer to it as a "weak" option and Cummins also finds a rapid transition to English unsound; Baker and Jones, eds., Encyclopedia of Bilingualism and Bilingual Education (Clevedon UK: Multilingual Matters, 1998), 476-82; Jim Cummins, "The Role of Primary Language Development in Promoting Educational Success for Language Minority Students," in Schooling and Language Minority Students (Los Angeles: California State University, 1981), 3-49. At Churchill's Stage 5, it is recognized that the minority language is "threatened" and the minority has a right to maintain it; at Stage 6, the minority language has equality with the state language: The Education of Linguistic and Cultural Minorities, 55.

120 Churchill, The Education of Linguistic and Cultural Minorities, 55; Sandra Clarke and Marguerite MacKenzie, "Education in the Mother Tongue: Tokenism versus Cultural Autonomy in Canadian Indian Schools,” Canadian Journal of Anthropology 1, 2 (1980): 205-17. Mohawk and Cayuga immersion programs were initiated in September 1986 among the Six Nations of Grand River. See Amos Key, "History of the Six Nations Immersion Program,” six-page ms. in the author’s possession. 
instruction threatened the very foundation of DIAND's education system and its historic policies of assimilation.

DIAND schools in Ontario were mirror images of schools under provincial jurisdiction, except that instead of French they had a Native language and the Native-language teachers generally worked in isolation, with little or no support. The Ojibway-Cree Cultural Centre provided limited assistance to Native-language teachers in northern Ontario but it did not have "the direct access to schools and an ongoing inservice process to provide meaningful program support.”121

This study of the little-known Northern Native-Languages Project has summarized the NNLP's key recommendations, described reactions to the NNLP by Native organizations, the Ontario Ministry of Education and DIAND, analyzed the policy making process, and noted the NNLP's policy impacts. ${ }^{122}$ The NNLP identified a key problem in northern Ontario education: there was a "lack of consistent information about language education for northern schools" that "made it difficult to develop policies, plan programs, train personnel and produce educational materials in an effective and coordinated" manner. ${ }^{123}$ We have seen that a key DIAND official, Art Griffith, did not or could not endorse the Final Report's recommendations concerning vernacular education. Ontario's Minister of Education acquiesced, and the two governments focused their efforts on preparation and certification of Native-language teachers, and teaching Native languages as subjects of instruction. For vernacular-language education, the policy decision was to maintain the status quo whereby English (or French) was the dominant language of instruction in Ontario for Native peoples. Native education in Ontario remained focused on a "learner-deficit" model.

Indian Control of Indian Education, the National Indian Brotherhood's 1972 manifesto, was twisted by DIAND to justify the devolution of specific programs to Indian bands and organizations, especially complex (and potentially costly) issues like Native culture and Native language. Indian opinion could be ignored when it challenged the agendas of DIAND officials, as when the Education Council supported the Final Report of the NNLP in 1980. Conversely,

121 Paquette, Aboriginal Self-Government and Education, 59, 61.

122 It is mentioned in Burnaby, "Language Shift"; Burnaby, Language in Education, 42; Burnaby, Aboriginal Languages in Ontario, 27; Toohey, "Case Study of Fort Albany,” 46; Paquette, "Purpose, Parity and Conflict," 65; Emily Jane Faries, "Language Education for Northern Native Children: A Case Study" (Ed.D. diss., University of Toronto, 1991), 13, 17, 24-25; George Taylor Fulford, "Children's Drawings in a Maskeko ('Swampy Cree') Community” (Ph.D. diss., McMaster University, 1994).

123 Burnaby, Nichols, and Toohey, "Final Report," 1. 
the need to consult with chosen "representative" Indians could be deemed essential, as in DIAND's 1983 response to a bold Ministry initiative. DIAND could justify establishing university linguistic programs with reference to Indian control, as it did in 1982. It also could, and did, limit the meaning of Indian control by burying the Final Report of the NNLP and refusing to translate it into Cree and Ojibwe, delaying Indian communities' access to more effective models of bilingual education. DIAND's commitment to Aboriginal languages may have appeared to be merely rhetoric, a common feature in colonial situations. ${ }^{124}$ More likely, it was intentionally adopted by the federal government as a symbolic policy that was never intended to have any real impact. ${ }^{125}$

In 1998 the federal government apologized for the role of its residential school system in preventing Aboriginal children "from speaking their own languages and learning about their heritages and cultures." ${ }^{26}$ Although 90 per cent of the claims from former residential school students seek compensation for loss of language and culture, Canada has refused to consider such claims, arguing that language loss was experienced by "all Aboriginal people and not just those individuals who attended residential schools.”

Assimilation has been the goal of Canada's Indian policy for over 150 years. Earlier tools, like residential schools, may have found disfavour, but they have merely been replaced by more subtle means. ${ }^{128}$ In 1983, federal and provincial governments consciously decided not to recognize Native languages as languages of instruction for Native students in Ontario. In rejecting a policy of vernacularlanguage education for Native students attending day schools, both

124 Paul Morris and Ian Scott, "Educational Reform and Policy Implementation in Hong Kong,” Journal of Education Policy 18, 1 (2003): 71-84.

125 James J. Scheurich, "Policy Archaeology: a new policy studies methodology," Journal of Education Policy 9, 4 (1994): 297-316. I am grateful to Jerry Paquette for this reference.

126 "Statement of Reconciliation" (Canada: DIAND, 1998), <http://www.aincinac.gc.ca/gs/rec e.html > retrieved 5 June 2003.

127 "National resolution framework announced for victims of abuse at Indian residential schools" (Canada Indian Residential School Resolution, 2002), <http://www.irsrrqpa.gc.ca/english/news_20_12_02.html >, retrieved 24 March 2003. This wording on this website was subsequently replaced with "These claims are to be addressed by current federal programming that supports Aboriginal languages worth some \$30M per year. In addition, it is anticipated that the recently announced $\$ 172.5 \mathrm{M}$, through the federal department of Canadian Heritage, will speak fully to the needs of former students, their communities and the inter-generational needs of Aboriginal people.” Retrieved 5 June 2003.

128 John L. Tobias, "Protection, Civilization, Assimilation: An Outline of Canada's Indian Policy,” Western Canadian Journal of Anthropology 6, 2 (1976): 13-30. See also Sally M. Weaver, Making Canadian Indian Policy: The Hidden Agenda, 1968-70 (Toronto: University of Toronto Press, 1981). 
governments arguably contributed to the further erosion of Native languages at a time when they were more vulnerable than ever, due to the arrival of television in the north. ${ }^{129}$ Policy decisions alone do not guarantee the survival of endangered languages, but they can offer them some important "symbolic space." 130

Thanks to all who contributed their insights and recollections (interviewees were given the choice of using own name or a pseudonym): former NNLP researchers Barbara Burnaby, John $D$. Nichols, and Kelleen Toohey; former NNLP co-chairs Marianna Couchie and Keith Lickers; former DIAND officials Gord Mullin, "Art Griffith” (a pseudonym), John Donnelly, Gary Maxwell, Fred Hunter, Mac Hall, Mary Mitchell, John Connor, "Larry Sands” (a pseudonym), Ifka Filipovich, and Ron Penner; former Minister of Education Bette Stephenson and former Deputy Minister of Education Harry K. Fisher; former Circle Program writer/researcher Mary Upper; Alex Spence, Kathy Spence, Greg Spence, Marylou Iahtail, Simon Frogg, Dennis Austin and Norm Wesley, all formerly staff of the Ojibway and Cree Cultural Centre; Jim Morris and Pat Ningewance, formerly of Wawatay Native Communications Society; and Richard Morris of the Northern Nishnawbe Education Council; Verna Kirkness; Adrian Tanner; Richard J. Preston. An Internal Research Grant from Nipissing University, and support through the Nipwork program, are gratefully acknowledged. The author acknowledges with thanks the contributions of three research assistants: Anne Marie Breckon, Leslie Oxley, and Cindy Caplette. The editors and anonymous reviewers also offered very helpful advice. This article is dedicated to the late Sally M. Weaver, whose course on "The Contemporary Indians of Canada" helped to start me on this journey of discovery and transformation.

129 Ningewance, Dreaming in a Strange Language; Norris, "Canada’s Aboriginal Languages.”

130 Fettes, "Life on the Edge”; Romaine, "Impact of Language Policy.” 